\title{
A Study into the Nature and Consequences of Tax Evasion with Special Reference to India
}

\author{
M. M. Sury*
}

\begin{abstract}
Tax evasion is a serious problem in developing countries which are in the process of evolving their tax systems. The major causes of tax evasion include high level of tax rates, apathy towards government and its laws, and lenient penal action. Widespread tax evasion is a perennial problem of the Indian tax system. The paper looks at the history of taxation law amendments in India which is essentially a history of plugging loopholes, as and when discovered, to prevent leakages of revenue. To fight the evil of black money and tax evasion in India, some of the important measures taken include reduction in tax rates, minimisation of controls and licences, regulation of donations to political parties, creating confidence among small taxpayers, substitution of sales tax by excise duty, vigorous prosecution policy and compulsory maintenance of accounts.
\end{abstract}

Keywords: Tax evasion, Transfer pricing, Tax amnesties, Penalties, Income tax.

\subsection{Introduction}

Tax evasion exists in all countries, though in varying degrees. It is a serious problem in developing countries which are in the process of evolving their tax systems. Tax evasion is an illegal attempt to reduce the tax payable by deliberately under-reporting or not reporting taxable incomes or concealing one's true state of affairs from tax authorities. Tax evasion is a criminal offence and if detected is punishable by financial penalties or even by imprisonment or both.

In contrast to tax evasion, tax avoidance means preventing or reducing one's tax liability through manipulations within the framework of existing tax legislation. Tax avoidance, as against tax evasion, is legally permissible and hence a legitimate aim of taxpayers.

*Formerly Economic Advisor - Delhi State Finance Commission, Formerly Reader, University of Delhi, Delhi. 
2 | VISION: Journal of Indian Taxation, Volume 2, Issue 1

Tax avoidance is resorted to through such devices as formation of holding companies to claim artificial deductions, constitution of trusts and family partnerships, transfer of income earning assets to one's wife and children for fractioning income for tax purposes, investing in provident funds and life insurance policies, and manipulation of capital gains. Since tax avoidance has a colour of legality about it, clever taxpayers do their best to avoid or keep down tax payments. This may force the government to raise tax rates, making the less clever assessees bear a disproportionate tax burden.

Tax laws in many countries incorporate anti-tax avoidance provisions under which certain incomes are included in an assessee's total income, though such incomes legally belong to other persons. For example, in India, sections 60 to 65 of the Income Tax Act, 1961, deal with instances where an assessee may attempt to reduce his tax liability either by transferring his assets in favour of his family members or by arranging his sources of income in such a manner that tax incidence falls on others, whereas benefit of income, directly or indirectly, is derived by the assessee himself. Thus, income arising to the spouse, minor child, son's wife, son's minor child and certain other persons are clubbed with the assessee's income in certain circumstances. In this regard, the Indian income tax law deviates from the general principle that a person can be assessed in respect of his own income.

\subsection{International Tax Avoidance and Evasion}

While it is true that international business operations are exposed to the risk of being subject to double taxation, it cannot be gainsaid that such activities provide opportunities for tax avoidance/evasion. Some of the devices generally applied for the purpose of international tax avoidance and evasion are explained below.

\subsection{Transfer Pricing}

It refers to the price attached to transactions between the divisions (e.g. branches or subsidiaries) of a company. Transfer pricing is usually considered in a global context, particularly in relation to cross-frontier transactions within a multinational company.

Determination of transfer price has significance in relation to such matters as taxation, exchange restrictions, and currency fluctuations. The incentive for transfer price manipulations is provided by varying rates of taxation in countries where a multinational company operates. Thus, where goods are being transferred from a company in a low tax country to a subsidiary company in a high tax country, there is a clear tax incentive if a high transfer price is ensured to maximise profit within the low tax country.

Similarly, sales of a multinational group may be routed through a specially 
formed tax haven distribution company. The tax haven company purchases goods from affiliated companies at the lowest possible prices and sells to independent purchasers at the full market price, ensuring that most or all of the profit from the transaction is earned in the tax haven.

Due to the inherent difficulties in determining a fair or market price for intercompany transactions, a multinational company has always the option to fix artificial transfer prices. To deal with the problem of transfer pricing, most of the countries recommend the use of arm's length price.

Arm's length price refers to the market price that would have been negotiated by unrelated parties engaged in the same or similar transactions under the same or similar conditions. Arm's length standard is used to prevent the use of transfer pricing technique for tax avoidance. Many countries exercise their right to adjust reported transfer prices to conform to an arm's length criterion. Implementing the arm's length principle is a difficult task for tax authorities.

\subsection{Tax Treaty Shopping}

It is a situation where a person resident in a third country seeks to obtain benefits of a double tax treaty between two other countries. A double tax treaty confers substantial benefits on the residents of treaty countries. Let us suppose that Mr. Wilson, resident in country A, wants to invest in country B. Assuming that there is no double tax treaty between country A and country B, any income received by Mr. Wilson will be subject to full rates of taxation in country B. In such a situation, Mr. Wilson may find it advantageous to channel his investment to country B through a company in country $\mathrm{C}$ because country $\mathrm{C}$ has double tax treaties with countries $\mathrm{A}$ and $\mathrm{B}$. For example, Mauritius is a popular treaty shopping haven for many foreign companies for channelling investments into India because of favourable tax treaty provisions.

To prevent the misuse of tax treaties through tax treaty shopping, many countries take care to include anti-treaty abuse provisions in these agreements. For example, there is a specific clause in the double tax treaty between India and USA under which benefits of the treaty are available only to genuine residents of either country. In other words, the treaty restricts the use of USA as a treaty shopping centre for investments in India.

\subsection{Causes of Tax Evasion}

This section explains the major causes of tax evasion by assesses. The major causes include high level of tax rates, apathy towards government and its laws, land lenient penal action. 
4 | VISION: Journal of Indian Taxation, Volume 2, Issue 1

\subsection{High Level of Tax Rates}

Among the host of causes of tax evasion and hence the generation of black money, the level of tax rates is probably the most crucial. It is widely believed that higher the rate of tax, the greater is the tendency to evade taxes. High tax rates make tax evasion more tempting. Tax evaders readily take greater risks if they know that in the event of success the reward is high. Per contra, it can be expected that low tax rates improve tax compliance and broaden the tax base.

\subsection{Less Respect for Government and its Laws}

Tax evasion is more in countries where there is general apathy on the part of people towards the government and its laws. People will have less respect for tax laws if they perceive the tax system to be unfair in terms of level of taxation (tax-GDP ratio) ${ }^{1}$ and/or distribution of tax burden among various classes (i.e. tax equity) ${ }^{2}$. Similarly, there can be a feeling among taxpayers that government is indulging in wasteful expenditure (e.g. digging the roads too often), spending excessively on government functionaries, permitting loan waivers, maintaining perpetually sick public undertakings, and granting unnecessary subsidies. Tax evasion by politicians sends wrong signals to the general public that non-compliance is acceptable.

It is necessary to change the attitude of the people towards Government and its laws. In this connection, the Indian Tax Reforms Committee, 1991, observed, “...there is a widespread feeling among the electorate that there is considerable waste in government expenditure, that there is excess staff and that the tail to teeth ratio is unduly high. And with it all, it is generally felt that the public which pays the taxes gets poor service and members of the public are treated often not as masters who pay but as supplicants." (Government of India, Interim Report of the Tax reforms Committee, 1991, p.44).

\subsection{Lenient Penal Action}

Lenient penal action in case violation of law is detected also encourages tax evasion. In general, countries with relatively poor implementation of regulations tend to have a higher share of unaccounted economy, whereas countries with properly implemented regulations and sound deterrence have smaller black economies.

\subsection{Nature of the Economy}

The problem of tax evasion in underdeveloped countries is associated with the peculiar characteristics of their economies which, in most cases, are agriculture-based in the sense that a substantial part of national income originates from and the majority of the work force is engaged in agriculture. Moreover, there is widespread illiteracy, lack of 
accounting practices, limited monetisation and shortage of administrative resources in these countries. A regime of controls, licences, and shortages also breeds tax evasion and black money.

\subsection{Consequences of Tax Evasion}

The nexus between tax evasion and black money and its distortion of the redistributive role of tax policy was noted by India's Seventh Five Year Plan (1980-85) as follows, "With a sizeable proportion of income and wealth evading taxation, the redistributive impact of progressive taxation had been severely blunted. A reduction in the scale of black income generation would improve distribution of income and wealth after taxation. Besides, if the magnitude of tax evasion is significantly reduced, there would be a greater volume of tax revenue, and a greater volume of public expenditure benefiting the poorer section of the population would become possible." (Government of India, The Seventh Five Year Plan (1985-90), Volume I, p. 71)

Black money in social, economic and political space of the country has a debilitating effect on the institutions of governance and conduct of public policy in the country. Governance failure adversely affects the interests of vulnerable and disadvantaged sections of society. The success of an inclusive growth strategy ${ }^{3}$ critically depends on the capacity of society to root out the evil of corruption and black money from its very foundations. Undoubtedly, India needs a speedy transition towards a more transparent and result-oriented economic system.

The effects of tax evasion, resulting in black money, on an economy are indeed disastrous. Some of these are listed below:

1. Tax evasion cuts at the very root of the revenue potential of a tax system and therefore hinders the resource mobilisation efforts of a government. Lack of funds may distort implementation of development plans and force a government to resort to deficit financing in case public expenditure is inelastic.

2. Tax evasion may interfere with the declared economic policies of a government by distorting saving/investment patterns and availability of resources for various sectors of the economy. For instance, government may impose credit restrictions to discourage certain activities (e.g. speculation) but money saved through tax evasion may finance and encourage the same activities.

3. Evasion of tax seriously undermines the equity attribute of a tax system. Honest taxpayers, who are obliged to bear disproportionate tax burden, feel demoralised and tempted to join the tax evaders' camp.

4. Tax evasion leads to the creation of black money which in turn is a menace to the 
6 | VISION: Journal of Indian Taxation, Volume 2, Issue 1

economy in its own way. Tax evasion and black money encourage concentration of economic power in the hands of undesirable groups in the country.

5. Tax evasion eats into the time and energy of tax administration which is obliged to unravel the intricate manipulations of tax dodgers.

6. Tax evasion leads to degradation of social and moral standards. Social abuses like bribery, intimidation, blackmailing, tampering with official records, submitting fake documents etc. all go with tax evasion.

With liberalisation of restrictions on cross-border flow of goods and services and relaxation of foreign exchange control, new opportunities have opened up for tax evasion through tax havens, misuse of transfer pricing, and other sophisticated methods. Globalisation has reduced the cost of these sophisticated methods thereby facilitating generation of black money and its transfer across the border. These changes require new strategies to curb black money.

The fight against generation and accumulation of black money is far more complex and prolonged, requiring stronger intervention of the state. It needs a robust legal framework, commensurate administrative set up, and a very strong resolve to fight the menace.

\subsection{Devices Adopted to Evade Taxes}

Various devices are adopted to evade taxes domestically and internationally. The techniques of evading some of the common taxes in the tax system are discussed below.

\subsection{Evasion of Specific Taxes}

A. Income Tax: Income tax is evaded through non-reporting, under-reporting and misreporting of income (e.g. showing non-agricultural income as agricultural income) ${ }^{4}$

The following devices are generally employed to evade income tax:

1. Non-reporting/under-reporting of taxable income.

2. Maintaining multiple set of account books, fraudulent changes in account books, and keeping transactions out of account books.

3. Opening and operating bank accounts under assumed names.

4. Doing business in the name of dummies.

5. Over-reporting expenses.

6. Fragmenting income to reduce tax liability.

7. Under-invoicing sales and other transfer pricing manipulations.

Although evasion of tax is a common tendency among people belonging to different groups, opportunities for it vary according to the nature of income earned by taxpayers. In the case of income from salaries and interest from deposits, evasion is less likely 
because of proper recording and auditing of transactions, and deduction of tax at source. However, opportunities for tax evasion are very large in the case of self-employed in business and professions. Doctors, lawyers, architects, property dealers, individual contractors can evade taxes more easily than others. They can insist on their customers to pay them in cash or accept invoices which underestimate the payment.

B. Excise Duties: Excise evasion is generally resorted to by adopting, inter alia, following malpractices.

1. Incorrect accounting of goods.

2. Undervaluation of goods.

3. Flouting the conditions subject to which any goods may be exempted from duty.

C. Value-Added Tax (VAT): The proponents of VAT claim that evasion under it is difficult and minimal. The tax credit method ensures cross-checking of the records of taxpayers through invoices. Buyer firms insist on supplier firms to furnish invoices which help the former to claim tax credit. Since tax liability of a single taxpayer under VAT is only a fraction of the total amount of tax, the incentive for evasion is relatively weak. Even a successful evasion would mean less revenue loss as compared to the one suffered under a system of turnover tax on gross value (excise duty or sales tax).

Despite the self-policing nature of VAT, opportunities do exist under it for evasion and fraud. In fact, VAT provides opportunities for fraud (fictitious claims for refunds) which are not available under other forms of commodity taxation. The methods commonly applied to defraud tax authorities under VAT include, inter alia, the following.

1. Use of fake invoices to claim tax credit.

2. Tax credit claims on purchases for personal use.

3. Over-reporting of sales of zero-rated goods.

4. Secret deals between buyers and sellers as regards issuance of receipts.

5. Formation of fake companies which sell receipts to traders to enable them to claim tax credit on inputs.

Thus, VAT is as susceptible to evasion and fraud as any other tax. An efficient tax machinery capable of cross-checking a large number of invoices through an elaborate computer system is a pre-requisite for the successful implementation of VAT.

D. Customs Duties: Evasion of customs duties takes place through following malpractices.

1. Invoice misclassification.

2. Manipulation of documents.

3. Suppression of quantities imported. 
8 | VISION: Journal of Indian Taxation, Volume 2, Issue 1

\subsection{Tax Havens}

The term tax haven has been widely used since the 1950s. However, there is no precise definition of the term. The expression is used to describe any country or locality which levies very low taxes, or none at all, on foreigners. Tax havens can be broadly classified into three categories based on the degree of tax concessions.

1. Where there is no tax at all, e.g. Bahamas, Bermuda, and Cayman Islands.

2. Where only a low rate of tax is imposed, e.g. British Virgin Islands, Hong Kong, Isle of Man.

3. Where the tax system favours particular activities or entities, e.g. Luxembourg, Panama, and Switzerland.

Tax havens are used in a number of ways to avoid/evade high taxes of non-tax haven countries. The commonest device is to use a tax haven only as a conduit for transactions the real economic impact of which is located elsewhere. Thus, international transactions between two high tax rate countries may be channelled through a tax haven company so that any resulting profit is realised in the tax haven with a consequent minimisation of tax.

The Organization for Economic Co-operation and Development (OECD) initially defined tax havens as being characterised by no or very low taxes, lack of effective exchange of information, and lack of transparency about substantial activities. It listed 35 countries/jurisdictions as tax havens in the year 2000.

A. Offshore Financial Centres: Some of the old tax havens have adopted the more benign designation of offshore financial centre (OFC) and tend to describe themselves as financial centres specializing in non-residential financial transactions. However, with their array of secrecy provisions that lack regulation, zero or near zero taxation imposed by them, and lack of adequate capital controls, they are logical extensions of the traditional tax havens. The International Monetary Fund (IMF) has defined OFCs as centres where the bulk of financial sector transactions on both sides of the balance sheet are with individuals or companies that are not residents, where the transactions are initiated elsewhere, and where the majority of the institutions involved are controlled by non-residents. Thus, many OFCs have the following characteristics:

1. Jurisdictions that have financial institutions engaged primarily in business with nonresidents.

2. Financial systems with external assets and liabilities out of proportion to domestic financial intermediation.

3. Centres which provide some or all of the following opportunities: (a) low or zero taxation, (b) moderate or light financial regulation, and (c) banking secrecy and anonymity. 
Various studies on tax havens have shown that tax havens are typically small countries/jurisdictions, with low or nil taxation for foreigners who decide to come and settle there. They usually also offer strong confidentiality or secrecy regarding wealth and accounts, making them very attractive locations for safe keeping of unaccounted wealth. They also offer a very liberal regulatory environment and allow opaque existence, where an entity can easily be set up without indulging in any meaningful commercial activity and yet claim to be a genuine business unit, merely by getting itself incorporated or registered in that jurisdiction. This makes them highly desirable locations for multinational entities wishing to reduce their global tax liabilities. These multinational entities — consisting of a network of several corporate and non-corporate bodies - may set up conduit companies in tax havens and artificially transfer their income to such conduit companies in view of the low tax regime there. There is increasing global awareness and concern about the role of tax havens and their facilitation of certain abusive and undesirable arrangements that result in significant fiscal challenges to other countries and also pose a threat in terms of potential financing of terrorism and other activities that threaten peace and security.

The role of tax havens has gradually come under scrutiny globally. With near-zero tax regimes, banking secrecy, and weak financial regulations, these tax havens facilitate hiding of money accumulated through tax evasion and other illegal means in addition to creating risks of terrorist financing and money laundering. At the G-7 summit in Lyons in 1996, a call was given to the OECD to prepare a report to address these issues with a view to establishing a multilateral approach under which countries could operate individually and collectively to limit the extent of these practices. The OECD came up with a report in 1998 and called for action against tax havens. The report envisaged blacklisting of and internationally coordinated sanctions against havens that persisted in luring other states' tax bases.

\subsection{Participatory Notes (PNs)}

A participatory note (PN) is a derivative instrument issued in foreign jurisdictions, by a foreign institutional investor (FII)/or one of its associates, against underlying Indian securities. PNs are popular among foreign investors since they allow these investors to earn returns on investment in the Indian market without undergoing the significant cost and time implications of directly investing in India. These instruments are traded overseas outside the direct purview of Securities and Exchange Board of India (SEBI) surveillance thereby raising many apprehensions about the beneficial ownership and the nature of funds invested in these instruments. Concerns have been raised that some of the money coming into the market via PNs could be the unaccounted wealth camouflaged 
under the guise of FII investment. SEBI has been taking measures to ensure that PNs are not used as conduits for black money or terrorist funding.

\subsection{Investment through Complex Derivative Instruments}

With increasing sophistication of derivative instruments ${ }^{5}$, new opportunities for investing and making profits without being subjected to taxes and regulations are also opening up. Such innovative means can also be misused by unscrupulous parties to generate unaccounted income. Some such instruments like participatory notes may not be adequately covered by regulatory mechanisms and their oversight and hence have potential for misuse.

\subsection{Various Estimates of Tax Evasion in India}

Widespread tax evasion is a perennial problem of the Indian tax system. The history of taxation law amendments in India is essentially a history of plugging loopholes, as and when discovered, to prevent leakages of revenue.

\subsection{Early Attempts}

The problem of tax evasion and generation of black money is not new. As far back as 1936, the Ayers Committee, while reviewing the income tax administration in India suggested large-scale amendments to secure the interests of the honest taxpayer and effectively deal with fraudulent evasion.

The Income Tax Investigation Commission was appointed in 1947 to investigate tax evasion and suggest measures for preventing it in future. Soon after Independence in 1947, the Indian Income Tax Investigation Commission, 1948, investigated all matters relating to taxation of income, with particular reference to preventing evasion and avoidance. The Commission recommended several changes in the law to plug loopholes in the income tax system. It recommended, inter alia, that the law should be amended so as to allow speculative losses to be set off only against speculative gains.

Since early 1950s, various commissions, committees and individual scholars have made estimates of tax evasion in India, particularly evasion of income tax. The findings of these studies are summarised below chronologically.

\subsection{Taxation Enquiry Commission (TEC) [Chairman: John Matthai], 1953-54}

TEC which dealt at length with the administration of income tax, found staggering levels of tax evasion. To quote, "It is observed from statistics in connection with the Disclosure Drive that income as originally included in the returns sent to the income tax department by assessees who made disclosures was grossly understated, the difference 
between the income as originally returned and that disclosed later to the department being, on the average, as much as 600 percent. Such other statistics as have been made available to us by the Central Board of Revenue also give evidence of the fact that evasion is prevalent on a considerable scale" (Government of India, Report of the Taxation Enquiry Commission, 1953-54, Volume II, p. 189). The Commission maintained that improvement and strengthening of the enforcement machinery was the only way to tackle evasion effectively.

\subsection{Estimates of Nicholas Kaldor}

Nicholas Kaldor, a British economist, made the first systematic estimates of income tax evasion in India in the mid-1950s. He estimated income tax loss through tax evasion at Rs. 200 to Rs. 300 crore for the year 1953-54 (Kaldor, 1956, p.105). The estimates of Kaldor were based on certain tentative figures relating to national income provided to him by the Central Statistical Organisation (CSO). Kaldor made it clear in his report that his estimates were tentative and should be interpreted with caution. His recommendations resulted in several amendments to the Income Tax Act and new legislations like the Wealth Tax Act.

\subsection{Central Board of Revenue}

Another study by the Central Board of Revenue for the same year (1953-54) recorded a much lower estimate of tax evasion at Rs. 20 to Rs. 30 crore, almost one-tenth of Kaldor's estimate (Government of India, Report of the Direct Taxes Administration Enquiry Committee, 1958-59, p. 148). One main reason for the wide divergence between the two estimates was the inclusion in Kaldor's estimate of what the Central Board of Revenue counted as avoidance rather than evasion. Kaldor himself had admitted while tendering oral evidence before Direct Taxes Administration Enquiry Committee, 1958-59, that his estimate represented the loss of tax not only through evasion but also through avoidance. Therefore, it is generally agreed that the estimates of income tax evasion by Kaldor were on the high side.

\subsection{Direct Taxes Enquiry Committee (DTEC) [Chairman: Justice K.N. Wanchoo], 1971}

DTEC (Government of India, Final Report of Direct Taxes Enquiry Committee December 1971) was appointed in 1971 to examine and suggest legal and administrative measures for unearthing black money and countering evasion and checking avoidance. It comprehensively dealt with the causes of and methods of tackling tax evasion and made a number of recommendations for strengthening tax administration. 
It estimated assessable non-salary income for the year 1961-62 at Rs. 2,686 crore and non-salary income actually assessed to tax to be of the order of Rs. 1,875 crore. Accordingly the income which escaped income tax was of the order of Rs. 811 crore. After making rough adjustments for exemptions and deductions, the Wanchoo Committee found that "the estimated income on which tax has been evaded (black income) would probably be Rs. 700 crore and Rs. 1,000 crore for the years 1961-62 and 1965-66 respectively". "Projecting this estimate further to 1968-69 on the basis of percentage increase in national income from 1961-62 to 1968-69, the income on which tax was evaded for 1968-69 was estimated as Rs. 1,800 crore."

\subsection{National Institute of Public Finance and Policy (NIPFP)}

In its study conducted in 1985, NIPFP defined black money as the aggregate of incomes which were taxable but which were not reported to tax authorities. The study made use of a range rather than a single figure of underestimation. While preparing the estimate of black income, the study excluded incomes generated through illegal activities like smuggling, black market transactions, and acceptance of bribes and kickbacks.

NIPFP study estimated the ratio of tax-evaded income to GDP in the range of 3.7 percent to 5.7 percent in 1975-76, and 4.2 percent to 8.6 percent in 1980-81 (Government of India, Aspects of the Black Economy in India, March 1985, p. 161).

\subsection{Tax Reforms Committee (TRC) [Chairman: Raja Chelliah], 1991}

According to TRC, "not more than 30-35 percent of legally taxable income is being disclosed, on the average" (Government of India, Interim Report of the Tax Reforms Committee, December 1991, p. 47). In this context it observed, "It would be fair to say that the income tax department which is in-charge of all the Central Government direct taxes is in shambles. It cannot complain of lack of manpower, but the majority of personnel is constituted by inspectors and clerks who are not adequately trained and are paid fairly low salaries."

Apart from the foregoing estimates, some evidence of general nature also suggests widespread non-reporting and under-reporting of taxable income in India. In this connection, the Finance Minister in his 1997-98 budget speech observed, "It is inexplicable that in a country of over 900 million people, only 12 million people are assessed to income tax and what is worse, only about 12,000 assessees are in the tax bracket of income above Rs. 10 lakh." (Government of India, Budget 1997-98, Speech of the Finance Minister, Part B, p. 25).

It is noteworthy that tax evasion is not confined to income tax only, rather it is widely practised for other direct taxes also like wealth tax. The ridiculously low yield 
from these taxes is partly due to plethora of exemptions/concessions and also due to widespread evasion. In India, economic inequalities have been caused mainly by the inequitable ownership of wealth and the failure of the wealth tax to make a headway in lessening inequalities is indeed regrettable.

It may be recalled that in 1957 and 1958, three new taxes were introduced, viz. wealth tax, expenditure tax, and gift tax. Estate duty was already in operation since 1953. The basic philosophy underlying the introduction of the system of integrated direct taxes was to prevent evasion and avoidance of direct taxes and thereby to reduce inequalities of income and wealth. However, the yield from wealth tax, expenditure tax, gift tax, and estate duty has never been of much significance in the Central tax structure. The meagre revenue collection ultimately led to the abolition of expenditure tax, estate duty and gift tax in 1966, 1985 and 1998 respectively. Wealth tax continues to be in operation.

Wealth tax liability is computed by applying the rate schedule to net wealth (i.e. taxable wealth). Presently (financial year 2013-14), wealth tax is charged at the flat rate of 1 percent in the case of all assessees having taxable wealth exceeding Rs. 30 lakh. In view of the meagre revenue and problems of administration and compliance, the Task Force on Direct Taxes (Chairman: Vijay Kelkar), 2002 recommended the abolition of wealth tax.

Estimation of evasion of indirect taxes in India has always remained a hard task even for the officially appointed committees. For example, the Central Excise (SelfRemoval Procedure) Review Committee, 1973, made extensive studies of excise evasion, both sector-wise and commodity-wise. However, it could not quantify the total magnitude of evasion. It observed, "we have reached the conclusion that evasion is considerable and, in certain sectors, pervasive. This is an inference we have drawn from the totality of what we have seen, heard and investigated." (Government of India, Report of the Central Excise (Self-Removal Procedure) Review Committee, 1973, p. 65)

\subsection{Agencies for Enforcement of Tax Laws in India}

\subsection{Central Board of Direct Taxes (CBDT)}

The CBDT, New Delhi, is part of the Department of Revenue in the Ministry of Finance. While the CBDT provides essential inputs for policy and planning of direct taxes in India, it is also responsible for administration of direct tax laws through its Income Tax Department. The CBDT is a statutory authority functioning under the Central Board of Revenue Act 1963. The officials of the Board in their ex-officio capacity also function as a Division of the Ministry dealing with matters relating to the levy and collection of direct taxes. 
The Income Tax Department is primarily responsible for combating the menace of black money. For this purpose, it uses the tools of scrutiny assessment as well as information-based investigations for detecting tax evasion and penalising the same as per provisions of the Income Tax Act, 1961 with the objective of creating deterrence against tax evasion. In doing so, it plays one of the most important roles in preventing generation, accumulation, and consumption of unaccounted black money.

The Investigation Wing of the Income Tax Department deals with investigations to detect tax evasion and carries out operations like surveys and searches to collect evidence of such evasion. Such operations are usually carried out after detailed preliminary investigations and in cases involving substantial evasion of taxes.

A. Directorate of Criminal Investigation (DCI): Till recently, the tax administration in India did not have a separate set-up for targeted investigation into criminal cases. On May 30, 2011, a notification was issued by the Government of India for creation of a Directorate of Income Tax (Criminal Investigation) or DCI in the Central Board of Direct Taxes, Department of Revenue, Ministry of Finance. The DCI is mandated to perform functions in respect of criminal matters having any financial implication punishable as an offence under any direct taxes law.

The DCI, in discharge of its responsibilities under the direct tax laws, is required to perform the following functions:

1. Seek and collect information about persons and transactions suspected to be involved in criminal activities having cross-border, inter-state, or international ramifications that pose a threat to national security and are punishable under the direct tax laws.

2. Investigate the sources and uses of funds involved in such criminal activities.

3. Cause issuance of show cause notices for offences committed under any direct tax law.

4. File prosecution complaints in the competent court under any direct tax law relating to a criminal activity.

5. Hire the services of special prosecutors and other experts for pursuing a prosecution complaint filed in any court of competent jurisdiction.

6. Execute appropriate witness protection programmes for effective prosecution of criminal offences under the direct tax laws, i.e. to protect and rehabilitate witnesses who support the state in prosecution of such offences so as to insulate them from any harm to their person.

7. Coordinate with and extend necessary expert, technical, and logistical support to any other intelligence or law enforcement agency in India investigating crimes having cross-border, inter-state or international ramifications that pose a threat to national 
security.

8. Enter into agreements for sharing of information and other cooperation with any central or state agency in India.

9. Enter into agreements for sharing of information and other cooperation with such agencies of foreign states as may be permissible under any international agreement or treaty.

10. Any other matter relating to the above.

The DCI is headed by a Director General of Income Tax (Criminal Investigation) and functions under administrative control of the CBDT. The head office of the DCI is located at New Delhi and it has eight regional offices all over India.

B. Exchange of Information (EoI) Cell: The Government of India has set up an EoI Cell in CBDT. The EoI works on the basis of mutual cooperation. The competent authorities of different countries provide different forms of administrative assistance to each other based on the provisions of Double Tax Avoidance Agreements (DTAAs) or the Multilateral Convention for Mutual Administrative Assistance. Administrative assistance under these instruments of EOI, depending on the terms of the agreement, may take the form of (a) specific exchange of information, (b) spontaneous exchange of information, (c) automatic exchange of information, (d) tax examination abroad, (e) simultaneous exchange of information, (f) service of documents, and (g) assistance in collection of tax.

C. Income Tax Overseas Units (ITOUs): With increased scope for international cooperation in areas of exchange of information, transfer pricing, and taxation of crossborder transactions, Government of India decided to create a network of ITOUs. In addition to the existing two ITOUs at Singapore and Mauritius, eight more have been opened. The objectives of these ITOUs are as under:

1. Monitor DTAA-related issues.

2. Assist the authorities in handling issues arising out of international taxation and transfer pricing.

3. Assist the authorities in frequent revision of existing DTAAs.

4. Assist the authorities in negotiation of TIEAs.

5. Expedite the exchange of information by the competent authorities (as per DTAAs and TIEAs) of these countries as required by the competent authority in India.

6. Assist the authorities in collection of taxes.

7. Assist the authorities in work relating to Mutual Agreement Procedure under DTAAs.

8. Maintain liaison with various departments of the respective countries especially Income Tax Department, Registrar of Companies, Department of Banking Services, and Administrators of Financial Services. 
9. Maintain liaison with investors investing in India from these countries.

10. Impart information about domestic laws of India to foreign investors.

11. Maintain liaison with Indian investors in these countries to assess any tax-related problems arising for these investors.

12. Assist the Mission in any other commercial/economic work assigned to the officer by the Head of the Mission.

13. Any other work assigned to the officer by the CBDT, Department of Revenue.

Opening of the new ITOUs and presence of tax officers in the ITOUs also acts as effective deterrence against tax evasion.

\subsection{Central Board of Excise and Customs (CBEC)}

The CBEC is a part of the Department of Revenue under the Ministry of Finance, Government of India. It deals with the tasks of formulation of policy concerning levy and collection of customs and central excise duties, prevention of smuggling, and administration of matters relating to customs, central excise and narcotics to the extent under the CBEC's purview. The Board is the administrative authority for its subordinate organizations, including Custom Houses, Central Excise Commissionerates, and the Central Revenues Control Laboratory.

The Directorate General of Central Excise Intelligence (DGCEI) is the apex intelligence organization functioning under the CBEC. It is entrusted with the responsibility of detecting cases of evasion of central excise and service tax. The Directorate develops intelligence, especially in new areas of tax evasion through its intelligence network across the country and disseminates information in this respect by issuing Modus Operandi Circulars and Alert Circulars to apprise field formations of the latest trends in duty evasion. Wherever found necessary, DGCEI on its own, or in coordination with field formations, organises operations to unearth evasion of central excise duty and service tax.

\subsection{Regulatory Authorities for Supervision and Policing}

\subsection{Central Bureau of Investigation (CBI)}

CBI, functioning under the Department of Personnel, Ministry of Personnel, Pension and Public Grievances, Government of India, is the premier investigating police agency in India. It handles a broad category of criminal cases including cases of corruption and fraud committed by public servants, economic crimes, and other specific crimes involving terrorism, bomb blasts, sensational homicides, kidnappings and the underworld. The CBI plays an important role in international cooperation relating to 
mutual legal assistance and extradition matters. The Ministry of Home Affairs is the central authority for mutual legal assistance in criminal matters and the Ministry of External Affairs the nodal agency for extradition matters.

\subsection{Financial Intelligence Unit (FIU)}

The FIU-IND was established by the Government of India on November 18, 2004 for coordinating and strengthening efforts for national and international intelligence by investigation and enforcement agencies in combating money laundering and terrorist financing. FIU-IND is the national agency responsible for receiving, processing, analysing, and disseminating information relating to suspect financial transactions. It is an independent body reporting to the Economic Intelligence Council headed by the Finance Minister. For administrative purposes, the FIU-IND is under the control of the Department of Revenue, Ministry of Finance.

\subsection{Narcotics Control Bureau (NCB)}

It functions under the Ministry of Home Affairs, Government of India. It was established on March 17, 1986 and its functions include co-ordination of actions by various offices, state governments, and other authorities under the Narcotics Drugs and Psychotropic Substances (NDPS) Act 1985, Customs Act, Drugs and Cosmetics Act, and any other law for the time being in force in connection with the enforcement provisions of the NDPS Act. It is assigned the task of counter measures against illicit drugs traffic under the various international conventions and protocols, and also assists concerned authorities in foreign countries and concerned international organisations dealing with prevention and suppression of this traffic.

\subsection{Co-ordinating Agencies}

\subsection{Central Economic Intelligence Bureau (CEIB)}

The CEIB functioning under the Ministry of Finance is responsible for coordination, intelligence sharing, and investigations at national as well as regional levels amongst various law enforcement agencies. The existing coordination mechanism in the CEIB consists of Regional Economic Intelligence Councils (REICs) at regional level and the Group on Economic Intelligence and meetings of the heads of investigating agencies under the Department of Revenue at the centre. While the Group on Economic Intelligence is focused on matters relating to intelligence sharing, the REICs and heads of agencies meetings cover both intelligence and investigations. 


\subsection{National Investigation Agency (NIA)}

It is a specialised and dedicated investigating agency set up under the National Investigation Agency Act to investigate and prosecute scheduled offences, in particular offences under the Unlawful Activities (Prevention) Act, including Financing of Terrorism. The NIA has concurrent jurisdiction with the individual states, thereby empowering the Central Government to probe terror attacks in any part of the country. Officers of the NIA have all powers, privileges, and liabilities which police officers have in connection with investigation of an offence.

The Central Government has the power to suo moto assign a case to the NIA for investigation. The NIA Act also provides for setting up of special courts and trials to be held on a day-to-day basis. The NIA Act can investigate offences under the specific Acts mentioned in the Schedule to NIA Act, including the Atomic Energy Act 1962, Unlawful Activities (Prevention) Act 1967, Anti-Hijacking Act 1982, Suppression of Unlawful Acts against Safety of Civil Aviation Act 1982, SAARC Convention (Suppression of Terrorism) Act 1993, Suppression of Unlawful Acts against Safety of Maritime Navigation and Fixed Platforms on Continental Shelf Act 2002, Weapons of Mass Destruction and Their Delivery Systems (Prohibition of Unlawful Activities) Act 2005, and offences under Chapter VI and Sections 489-A to 489-E of the Indian Penal Code.

\subsection{Other Agencies}

\subsection{Central Bureau of Narcotics (CBN)}

It supervises the cultivation of opium poppy in India and issues necessary licences for manufacture, export and import of narcotics drugs and psychotropic substances. It monitors India's implementation of the United Nations Drug Control Conventions and also interacts with the International Narcotics Control Board (INCB) in Vienna and the competent authorities of other countries to verify the genuineness of a transaction prior to authorising shipments.

\subsection{Serious Frauds Investigation Office (SFIO)}

It functions under the Ministry of Corporate Affairs and takes up for investigation complex cases having inter-departmental and multidisciplinary ramifications and substantial involvement of public interest, either in terms of monetary misappropriation or in terms of persons affected. It also takes up cases where investigation has the potential of contributing towards a clear improvement in systems, laws, or procedures. 


\subsection{Registrar of Companies (ROCs)}

It is the Registry for companies and limited liability firms and is established under the Ministry of Corporate Affairs. The Ministry of Corporate Affairs has a three-tier organisational set-up consisting of a Secretariat in New Delhi, Regional Directorates in Mumbai, Kolkata, Chennai and Noida, and field offices in all states and union territories.

\subsection{Registrar of Societies (ROSs)}

The Registrars of non-profit societies are within State Government's purview and most of the states have an ROS office. The Society Registration Act is a Central Act but many states have adopted it with some state amendments and are registering non-profit societies under their respective Acts. Some state assemblies have enacted completely separate legislation on the subject. The ROS offices are reservoirs of data on societies and also function as their regulator.

\subsection{Economic Intelligence Council (EIC)}

It came into existence in 2003 and is chaired by the Finance Minister and comprises senior functionaries of various ministries and intelligence agencies, including the Governor of the Reserve Bank of India (RBI) and the Chairman of Securities and Exchange Board of India (SEBI). The EIC meets at least once a year to discuss and take decisions regarding trends in economic offences and strategies on intelligence sharing, coordination etc. The implementation of decisions taken by the EIC is monitored by the Working Group on Intelligence Apparatus, set up for this purpose within the EIC.

\subsection{National Crime Records Bureau (NCRB)}

It was set up with the objective of empowering the Indian police services with information technology and criminal intelligence with a view to enabling them to effectively and efficiently enforce the law. It therefore creates and maintains a secured national database on crimes, criminals, property, and organised criminal gangs for use by law enforcement agencies. The NCRB also processes and disseminates fingerprint records of criminals, including foreign criminals, to establish their identity.

\subsection{State Police Agencies}

Under the Constitution of India, police and public order are state (provincial) subjects. Every State/Union Territory has its own police force, which performs not only normal policing duties but also has specialised units to combat economic offences. The Economic Offences Wing (EOW) of the police functioning under the administrative control of states (provinces) is entrusted with the responsibility of investigation of 
serious economic offences and offences having inter-state ramifications.

\subsection{Measures Adopted to Curb Tax Evasion}

Direct Taxes Enquiry Committee (Chairman: Justice K.N. Wanchoo), 1971, had suggested various measures to fight the evil of black money and tax evasion. Some of the measures suggested were as follows.

1. Reduction in tax rates.

2. Minimisation of controls and licences.

3. Regulation of donations to political parties.

4. Creating confidence among small taxpayers.

5. Substitution of sales tax by excise duty.

6. Vigorous prosecution policy.

7. Compulsory maintenance of accounts.

To give effect to the recommendations made by the Committee, the Government enacted the Taxation Laws (Amendment) Act, 1975. This Act, inter alia, provided stringent punishment for tax evaders. In cases where tax evasion exceeded Rs. 1 lakh or prosecution was for the second or subsequent offence, the maximum punishment prescribed was 7 years rigorous imprisonment. Also, the discretionary powers to courts to award monetary punishment as an alternative to imprisonment or to reduce the term of imprisonment less than the minimum period, was withdrawn.

Efforts have been made to curb tax evasion and control black money through various measures: Some of these are described below.

1. Lowering of tax rates.

2. Tax amnesties.

3. Advance tax payment.

4. Withholding tax [or tax deduction at source (TDS)].

5. Presumptive tax for small traders.

6. Permanent Account Number (PAN) or General Index Register Number (GIR).

7. Survey of income tax.

8. Summons, and search and seizure.

9. Restrictions on the transfer of high value immovable properties

10. Penalties and prosecutions.

\subsection{Lowering of Tax Rates}

The Report of the Direct Taxes Enquiry Committee (DTEC), 1971, was a milestone in the area of income tax rates. The Committee made a number of far-reaching suggestions for unearthing black money, preventing evasion and avoidance of taxes, and 
reducing arrears. One important recommendation of the Committee related to reduction in the rates of direct taxes which in its view were mainly responsible for tax evasion because they made tax evasion profitable and attractive. The rates of individual income tax were quite high till the year 1973-74. These high rates, necessitated by contingencies like drought and war, when combined with the prevailing shortages, resulted in controls and licences, and thereby provided further incentives for evasion of taxes. It was largely in this economic environment that generation of black money became highly prevalent and acquired serious proportions.

However, pursuant to the recommendations of the DTEC, the Government initiated a series of rate reductions in individual income tax. The top marginal rate of tax was reduced from 97.7 percent in 1973-74 to 77 percent in 1974-75, and further down to 66 percent in 1976-77. It is noteworthy that DTEC had recommended a maximum marginal rate of 75 percent. (Government of India, Final Report of Direct Taxes Enquiry Committee, 1971, para 2.52).

The downward trend in the rate of income tax was temporarily reversed during the brief Janata Government rule at the Centre. The top marginal rate of income tax was increased from 66 percent in 1976-77 to 69 percent in 1977-78, and further up to 72 percent in 1979-80. However, the policy of low direct tax rates started by the Congress Government in 1974 and carried forward in 1976 was further reinforced after it came back to power at the Centre in 1980. After a series of revisions, the maximum marginal rate of individual income tax was 54 percent (including employment surcharge of 8 percent), applicable from the financial year 1990-91.

Consequent upon the recommendations contained in the Interim Report of the Tax Reforms Committee (Chairman: Raja Chelliah), 1991, the top marginal rate was fixed at 44.8 percent (including surcharge) from the financial year 1992-93. The Finance Act, 1994 abolished the surcharge of 12 percent and hence the maximum marginal rate of tax was 40 percent from the financial year 1994-95. From the same year it was made applicable on incomes over Rs. 1,20,000. It may be recalled that the top marginal rate of income tax applied to incomes above Rs. 1 lakh from 1967-68 to 1993-94. The Rs. 1 lakh of 1967-68 was approximately equivalent to Rs. 5.5 lakh of 1993-94. This showed the laxity of the administration in adjusting tax brackets for inflation. It is noteworthy that Tax Reforms Committee had recommended 40 percent maximum rate inclusive of surcharge for income exceeding Rs. 2 lakh.

The maximum marginal rate of personal income tax was further reduced from 40 percent to 30 percent in the 1997-98 budget. In another significant move, it was made applicable to incomes above Rs. 1,50,000.

Low tax rates are welcome provided they improve compliance and revenue 
yield. However, to expect that lowering of rates would improve compliance automatically is unrealistic because tax evasion occurs at all levels of income. As the Indian Direct Taxation Administration Enquiry Committee, 1958-59, observed, "While we cannot deny that the higher the rate of tax, the greater will be the temptation for evasion and avoidance, we feel that the tax rates by themselves are not to blame for the large extent of evasion in the country. Even if the rates of tax are reduced, evasion will still continue, because it exists at all levels of income." (Government of India, Report of the Direct Taxes Administration Enquiry Committee, 1958-59, p. 149).

\subsection{Tax Amnesties}

Government may provide opportunity, from time to time, to tax evaders to declare their past concealments of income and wealth without fear of being prosecuted. Tax amnesty (or impunity) is granted only for the past in order to secure better compliance and thus higher tax yield in the present and future. Tax amnesties (or voluntary disclosure schemes) bring concealed money in the open, broaden the base of investment and hence accelerate economic development.

However, tax amnesties are criticized on the grounds that they provide a premium on dishonesty and are unfair to honest taxpayers. Tax amnesties set bad precedents and encourage tax evaders in the hope that they will be let off leniently for their past sins any time in the future. Practically, the same group of tax evaders takes advantage of tax amnesties announced by the government. The honest taxpayers are demoralised and the tax enforcement machinery also loses respect in the eyes of the common man.

In India, tax amnesties with varied characteristics have been offered from time to time to unearth black money. These amnesties provided taxpayers immunity from interest, penalty, investigation or prosecution in exchange for disclosures of incomes which did not pay tax.

In 1951, a voluntary disclosure scheme was announced under which penal provisions of tax laws were relaxed to persuade tax evaders to disclose their unaccounted incomes. Under another scheme, announced in 1965, tax evaders were required to pay 60 percent of the disclosed income by way of tax and allowed to bring into books of account the remaining 40 percent.

Another scheme announced in 1975 provided for clubbing together of all black income irrespective of the years over which it was earned and treated as a block separately from other taxable income for the purpose of income tax liability. It provided for a concessional rate of tax ranging from 25 percent to 60 percent on income disclosed under the scheme.

A. Special Bearer Bonds: In 1981, Government offered Special Bearer Bonds to the 
public. The Bonds were redeemable after 10 years (i.e. in 1991) and carried 2 percent per annum simple rate of interest. The Bonds were marketable and the holders were not required to explain their origin. On their redemption, the holders were allowed to bring them into their books. The value of the Bonds and interest thereon were exempt from income tax and wealth tax till their redemption.

B. Voluntary Deposit Scheme, 1991: This scheme to mobilise unaccounted money was announced through the Voluntary Deposits (Immunities and Exemptions) Act, 1991. Under this scheme, any person could make a deposit with the National Housing Bank on or before January 31, 1992. Thereupon, 40 percent of such deposit was deducted and set apart as a special levy for financing slum clearance and low cost housing for the poor. The balance of 60 percent was credited to the depositor's account which he was allowed to withdraw in one or more instalments for any purpose specified by him. Persons who made deposits under this scheme were not required to disclose the sources of funds from which the deposits were made. Hence, the money deposited was completely immune from all sorts of inquiry and investigation.

C. Gold Bond Scheme, 1993: This scheme was introduced through the Gold Bonds (Immunities and Exemptions) Ordinance, 1993, promulgated by the President on January 31,1993 . The objective of the scheme was to mobilise idle gold reserves of the country to supplement official reserves and thereby strengthen the credit position of the country in the international market. The scheme allowed amnesty from the provisions of direct tax laws to induce persons to legitimise their unaccounted holding of gold.

The scheme remained open for subscription from March 15, 1993 to June 14, 1993. Subscription to the Gold Bonds was made in the form of gold only. The minimum limit for subscription was 500 grams of gold. There was no maximum limit. A subscriber was not required to disclose, for any purpose whatsoever, the nature and source of acquisition of the gold subscribed for the Gold Bonds, including the money with which the gold was acquired.

The Bonds matured after 5 years from the date of issue and were repaid in the form of gold. Besides, a lump sum interest of Rs. 40 per gram of gold for the period of 5 years was paid on maturity.

D. Voluntary Disclosure of Income Scheme (VDIS), 1997: In his 1997-98 budget speech, the Finance Minister announced the introduction of a Voluntary Disclosure Scheme to harness black money for productive purposes. The scheme was rechristened as Voluntary Disclosure of Income Scheme, 1997 by the Finance Minister while moving amendments to the Finance Bill in the Lok Sabha on May 7, 1997.

VDIS, 1997 announced by the Central Board of Direct Taxes on June 18, 1997 had the following provisions. 
1. The scheme came into force from July 1, 1997. Any eligible person could make a disclosure of income on or after this date. The last date for making the disclosure was December 31, 1997. Thus, the scheme lasted for six months.

2. A person could make a disclosure in respect of income chargeable to tax under the Indian Income Tax Act, 1961 for any assessment year.

3. The particulars furnished by a declarant were kept a secret. Nothing contained in any declaration was used against the declarant for the purpose of any proceedings relating to imposition of penalties or launching of prosecution under the Income Tax Act, 1961, Wealth Tax Act, 1957, Foreign Exchange Regulation Act, 1973 or the Companies Act, 1956.

4. The tax payable on the disclosed income in respect of any assessment year was at the rate of 35 percent in the case of companies and 30 percent in the case of other assessees including individuals.

5. The tax payable under the scheme was to be paid before the filing of the declaration. In other words, the declaration was accompanied by the proof of payment of tax. In case a person was not in a position to pay the tax before the filing of the declaration, he was allowed to do so within three months of the date of filing of the declaration. In such a case, a simple interest at the rate of 2 percent was charged for every month or part of a month beginning from the date of filing of the declaration to the date of payment of the tax.

6. The declaration was made to the Commissioner of Income Tax in his area and was in a prescribed format. The declaration was signed in the case of an individual by the individual himself. In the case of a Hindu Undivided Family, company, firm etc. the declaration was signed and verified by persons specified in Section 65 of the Finance Act, 1997.

7. Where voluntarily disclosed income was represented by jewellery, the value of the jewellery or bullion was substantiated by a registered valuer's certificate. In case the jewellery declared was from a period before the financial year 1987-88, the value for purposes of declaration was taken to be value as on April 1, 1987.

8. The disclosure made in respect of any assessment year did not affect the finality of any completed assessment.

9. The voluntarily disclosed income was not added to the total income of the declarant if the declarant credited such amount in his books of account and intimated the credit so made to the Assessing Officer.

10. VDIS did not apply to the following categories of persons: (a) those on whom an order of detention had been served under the Conservation of Foreign Exchange and Prevention of Smuggling Activities Act, 1974 in certain circumstances, (b) those 
punishable under the Narcotic Drugs and Psychotropic Substances Act, 1985, (c) those punishable under the Terrorists and Disruptive Activities (Prevention) Act, 1987, (d) those notified under Section 3 of the Special Court (trial of offences relating to transaction in securities) Act, 1992, (e) those on whom notices under Section 142 or 148 had been served.

11. A person was not eligible for the income disclosure benefit if that income was before or for a year when a search had been initiated under Section 132 or a requisition made under Section 132A. However, persons surveyed under Section 133A of the Income Tax Act were barred from making a declaration only for income in the year of the survey.

12. State Governments got 77.5 percent of the total resources secured under the scheme. The remaining portion, being share of the Central Government, was used entirely to finance the Basic Minimum Services Programme and infrastructure needs.

At a press conference on January 3, 1998, Finance Minister P. Chidambaran announced that VDIS netted Rs. 10,050 crore towards tax revenue. The total disclosure of black money in the six-month-long campaign was Rs. 33,000 crore and an estimated 4.6 lakh declarations were made under the VDIS.

\subsection{Advance Tax Payment}

Though the regular assessment in respect of any income is made in a later assessment year, the tax on such income is payable by way of advance payment or deduction at source. Section 208 of the Income Tax Act, 1961 makes it obligatory to pay advance tax in every case where the advance tax payable is Rs. 10,000 or more.

\subsection{Withholding Tax [or Tax Deduction at Source (TDS)}

There are provisions under various sections of the Act regarding tax deduction at source (TDS) ${ }^{6}$, e.g. deduction of tax from salaries (Section 192). Other incomes covered under the scheme of TDS include fees for professional or technical services, interest, rent from real estate, commission from insurance, sale of lottery tickets, and winnings from lotteries, crossword puzzles and horse racing.

In recent years, improvement in the percentage share of direct taxes (mainly income tax) has taken place due to widening of the tax base, presumptive taxation and broadening the scope of TDS. In this context, the Ninth Five Year Plan (1997-2002) observed, "The share of TDS in gross collection of income tax increased from about 23 percent in 1980-81 to about 37 percent in 1989-90, but declined subsequently to about 31 percent in 1994-95. One of the major loopholes which contributes to the decline in revenue from TDS relates to the branch-wise threshold of Rs. 10,000 for the purpose of 
deducting income tax at source from interest on time deposits with banks. Further, the provision for TDS does not apply to non-banking financial companies. Other deficiencies from which the TDS scheme suffers arise from lack of proper monitoring and scrutiny."(Government of India, Ninth Five Year Plan (1997-2002), Volume I, p. 168).

\subsection{Presumptive Tax for Small Traders}

In its Interim Report, submitted in December 1991, the Tax Reforms Committee examined the problems and possibilities of taxing the small business sector. The Committee suggested two new presumptive taxes ${ }^{7}$ on small businesses:

1. A fixed tax on businesses whose turnover was less than Rs. 5 lakh.

2. An estimated income scheme on small businesses with a turnover above Rs. 5 lakh but less than Rs. 25 lakh.

The schemes envisaged profit to be a certain percentage of turnover depending on the type of activity from which it was earned. The Government introduced the first scheme through the Finance Act, 1992, but deferred its decision to introduce the second scheme.

The presumptive tax system for persons engaged in retail trade with an annual turnover up to Rs. 5 lakh was introduced on an experimental basis. The scheme was in operation initially for two assessment years 1993-94 and 1994-95. It was continued after the expiry of these two years. The objective of the new simplified procedure for taxation was to widen the tax base by encouraging shopkeepers (including those engaged in vocations like tailoring, typewriting, photocopying, repair work etc.) and other small retail traders to pay taxes. The scheme had the following features:

- The scheme was optional and open to individuals not assessed to tax earlier and who had an income from the business of retail trade having an annual turnover up to Rs. 5 lakh.

- Persons opting for the scheme were deemed to have a turnover of Rs. 5 lakh and their total income was deemed to be Rs. 35,000 (Rs. 37,000 for A.Y. 1994-95) on which the tax worked out to Rs. 1,400 after allowing for the basic exemption of Rs. 28,000 (Rs. 30,000 for A.Y. 1994-95).

- A retail trader opting for the scheme had only to file the simplified statement (name, address, nature of business etc.) and pay a tax of Rs. 1,400 by 15th March of the financial year in which the income was earned.

The scheme was optional to avoid objection on constitutional grounds. If presumptive tax results in a higher tax burden than the one on the basis of book profit, it can be said to violate Article 14 of the Constitution which guarantees equality before 
law. Thus, the taxpayer had the option to pay presumptive tax or ask for regular assessment of his income, whichever he thought was advantageous to him.

Unfortunately, the scheme of presumptive taxation did not gain popularity with small traders and self-employed entrepreneurs. In 1992-93, the first year of the operation of the scheme, 1,16,644 persons opted for the scheme and paid a total tax of Rs. 16.4 crore, as against the anticipated revenue collection of Rs. 140 crore. (Government of India, Economic Survey, 1993-94, p. 26). This was by no means a significant addition to the existing 70 lakh individual assessees under the income tax net. The number of shopkeepers and other small traders was much higher. The scheme touched only the tip of the iceberg.

The Government introduced through the Finance Act, 1994 two new schemes for estimating the income from the business of civil construction and plying or hiring trucks. The Finance Act, 1994 introduced Sections 44AD and 44AE in the Income Tax Act to provide for a method of estimating income from these businesses. While the section for civil construction applied to all assessees whose gross receipts from the business did not exceed Rs. 40 lakh, the section for plying trucks applied to businessmen owning not more than 10 trucks. Under Section 44AD, the income from these businesses was estimated at 8 percent of the gross receipts paid or payable to an assessee. Income of truck owners is assessed at Rs. 3,500 p.m. per heavy vehicle and at Rs. 3,150 p.m. per medium and light vehicle.

In the 1997-98 budget, the Finance Minister discontinued the presumptive scheme under Section $115 \mathrm{~K}$ as it failed to yield the desired results. In its place, he introduced a new estimated income scheme for retail traders. The new scheme is applicable to persons engaged in the business of retail trade of any goods or merchandise having a total turnover of less than Rs. 40 lakh. The income of the trader will be estimated at 5 percent of the total turnover. A trader with a turnover of less than Rs. 10 lakh is exempted given the present exemption limit of Rs. 50,000. Assessees who file a return showing an income less than 5 percent of turnover are required to maintain books of account and get their accounts audited.

A. Estimated Income Scheme for Small Businesses: This scheme, applicable for assessment year 2011-12 and onwards, applies to assessees engaged in any eligible business whose total turnover or gross receipts do not exceed Rs. 1 crore during a year. The scheme, under Section 44AD, is compulsory for all eligible assessees. Under the scheme, the income of an assessee from the eligible business is estimated at 8 percent of the total turnover in the previous year.

B. Estimated Income Scheme for Truck Owners: This scheme, provided under Section 44AE, applies to assesses engaged in business of plying, leasing or hiring 
trucks, owning not more than 10 trucks, at any time during the previous year. The income is estimated at Rs. 5,000 p.m. for each heavy goods vehicle and Rs. 4,500 p.m. for each vehicle other than heavy goods vehicle.

\subsection{Permanent Account Number (PAN) or General Index Register Number (GIR)}

In order to strengthen the efforts at enforcement, the Finance Minister in his 1998-99 budget made it obligatory for assessees to quote their PAN or GIR mandatorily in respect of the following high value transactions: purchase and sale of immovable property; purchase and sale of motor vehicles; transactions in shares exceeding Rs. 10 lakh; opening of new bank accounts; fixed deposits of more than Rs. 50,000; applications for allotment of telephone connections; and payments to hotels exceeding Rs. 25,000 .

\subsection{Survey of Income Tax}

Income tax authorities may conduct, from time to time, a shop to shop or house to house survey to rope in new assessees. Potential assessees are required to fill up a questionnaire in Form 45-D. Officials conducting the survey cannot seize any books of account, cash, or articles. If any person fails to comply with a notice under section 133B requiring the survey information in Form 45-D, he is liable to pay a penalty up to Rs. 1,000 (section 272AA of Income Tax Act, 1961).

\subsection{Summons, and Search and Seizure}

A. Summons: Under section 131 of the Income Tax Act, an authorised income tax officer can issue summons when he has reasons to suspect that any income has been concealed by any person within his jurisdiction. Summons is issued to enforce attendance of any person for the purpose of examining him. The person concerned may be examined to verify the authenticity of various types of transactions, the following being the common ones.

(a) Capital Contributions: Summons can be issued to owners of a business (i.e. proprietors, partners, and shareholders) to verify their capital contributions and sources of money thereof. Borrowed funds can be sources of money for capital contributions.

(b) Business Transactions: An assessee makes claim in his return of income regarding purchases, sales, revenue expenditure, and capital outlays. To verify such claims, the assessing officer can issue summons to suppliers, buyers, and recipients of commissions, salaries, rent. etc.

(c) Borrowing of Funds: An assessee may borrow funds from institutional and/or non-institutional sources for various purposes. Borrowings from non-institutional 
sources (e.g. private moneylenders, relatives, friends etc.) may need to be confirmed by income tax authorities. Hence, summons can be issued to persons who have lent money to explain sources of money lent.

(d) Investment Transactions: Summons can be issued to any person who has made substantial investments in shares, securities, land, buildings, and costly consumer durables. The person so summoned is expected to explain with documentary evidence the sources of his funds. These sources may include borrowings, gifts received, property inherited, sale of jewellery etc. However, documentary evidence is necessary to prove these sources of money. It is advisable to reveal correct factual information which can be cross-verified.

B. Search and Seizure: To conduct search (popularly called raid) and seizure, an authorisation in the prescribed form is issued by the competent income tax authority under his signature and seal. Income tax officials are vested with considerable powers to carry out search operations.

Thus, they can (a) enter and search any building, place or vehicle in occupation of the person being searched, (b) break the lock and examine any box, locker, almirah etc., (c) seize any books of account, other documents, money, bullion, jewellery etc.

Books of account and other documents impounded cannot be retained beyond 180 days without obtaining approval of the Commissioner. However, the assessee can have copies made out of the original books impounded by the authorities (sections 132, and 132A of the Income Tax Act, 1961).

\subsection{Penalties and Prosecutions}

These are as under:

A. Penalties: Income Tax Act contains provisions under which penalties are imposed for various defaults committed by the taxpayers. The important provisions in this regard are summarised in Table 1.

B. Prosecutions: Income Tax Act contains provisions under which prosecution proceedings can be started for different offences committed by taxpayers. The important provisions in this regard are summarised in Table 2.

C. Penal Provisions: A Comment: There are quite a few sections in the Income Tax Act which confer discretionary powers on income tax officers. Thus, Section 273A of the Act allows income tax officers to reduce or waive penalties for tax evasion if it is voluntarily disclosed before being discovered by the assessing officer. According to the Act, this can be done only once in the life time of a taxpayer. However, in practice it is likely that the penalty is waived several times for the same taxpayer even when the disclosure criterion is not met. 
Table 1: Select Penalty Provisions for Different Defaults under Income Tax Act, 1961

\begin{tabular}{|c|c|c|}
\hline Section & Nature of default & Penalty \\
\hline $271(1)(C)$ & Concealment of particulars of income & $\begin{array}{l}\text { Not less than the amount of tax } \\
\text { sought to be evaded and not } \\
\text { exceeding three times the amount of } \\
\text { tax sought to be evaded }\end{array}$ \\
\hline $271 \mathrm{~A}$ & $\begin{array}{l}\text { Failure to keep or maintain books of } \\
\text { account as required under section } \\
\text { 44AA }\end{array}$ & Rs. 25,000 \\
\hline $271 \mathrm{C}$ & Failure to deduct tax at source & $\begin{array}{l}\text { Amount equal to tax which he failed } \\
\text { to deduct or pay }\end{array}$ \\
\hline $271 \mathrm{~F}$ & $\begin{array}{l}\text { Failure to furnish return of income } \\
\text { under section } 139(1) \text { i.e. persons } \\
\text { owning immovable property, motor } \\
\text { vehicle, telephone etc. }\end{array}$ & Rs. 5,000 \\
\hline 272B & $\begin{array}{l}\text { Failure to apply for allotment } \\
\text { of Permanent Account } \\
\text { Number (PAN) }\end{array}$ & Rs. 10,000 \\
\hline
\end{tabular}

Table 2: Select Prosecution Provisions for Various Offences under Income Tax Act, 1961

\begin{tabular}{|l|l|l|}
\hline Section & \multicolumn{1}{|c|}{ Nature of offence } & \multicolumn{1}{c|}{ Punishment } \\
\hline $276 \mathrm{~B}$ & $\begin{array}{l}\text { Failure to deposit tax } \\
\text { deducted at source or tax } \\
\text { collected at source }\end{array}$ & $\begin{array}{l}\text { Rigorous imprisonment up to 7 years (not less } \\
\text { than 3 months) and fine }\end{array}$ \\
\hline 276 C(2) & $\begin{array}{l}\text { Wilful attempt to evade } \\
\text { the payment of any tax, } \\
\text { penalty or interest }\end{array}$ & $\begin{array}{l}\text { Rigorous imprisonment up to 2 years (not less } \\
\text { than 3 months) and fine }\end{array}$ \\
\hline 276CC & $\begin{array}{l}\text { Wilful failure to furnish in } \\
\text { due time return of income } \\
\text { or return of fringe benefits }\end{array}$ & $\begin{array}{l}\text { (a) Rigorous imprisonment up to 7 years (not } \\
\text { less than 3 months) and fine if the amount } \\
\text { sought to be evaded exceeds Rs. 25,00,000 } \\
\text { (b) Imprisonment up to 2 years (not less than 3 } \\
\text { months) and fine in other cases }\end{array}$ \\
\hline 277 & $\begin{array}{l}\text { Making a false statement } \\
\text { in verification or } \\
\text { delivering a false account }\end{array}$ & $\begin{array}{l}\text { (a) Rigorous imprisonment up to 7 years (not } \\
\text { less than 6 months) and fine if the amount } \\
\text { sought to be evaded exceeds Rs. 25,00,000 } \\
\text { (b) Rigorous imprisonment up to 2 years (not } \\
\text { less than 3 months) and fine in other cases }\end{array}$ \\
\hline
\end{tabular}


The possibility of misuse of section 273A cannot be ruled out. Similarly, section 273A (4) of the Act allows tax officers to reduce or waive penalty on grounds of genuine hardships. Furthermore, under section 279 (2) of the Act tax officers are empowered to compound an offence either before or after the institution of prosecution proceedings. These powers are discretionary and cannot be challenged in a court of law.

\section{Endnotes}

1. Level of taxation in a country is traditionally judged in terms of the ratio which taxes bear to some measure of national income. This ratio is called tax-GDP ratio and the change in it is determined by variations in both the numerator (total tax revenue) and the denominator (national income).

2. Tax equity refers to fair or just or equitable distribution of tax burden among taxpayers. Though fairness and justness in taxation are universally accepted, these terms are rarely defined rigorously and can be interpreted in various ways. Hence, there is no unanimity of opinion as to the type of tax system which results in the most equitable distribution of tax burden. There are two main approaches to tax equity in tax literature: the Benefit Principle of Taxation which states that tax payments should be proportional to the benefits derived from government services, and the Ability-to-Pay Principle of Taxation which holds that each taxpayer should contribute to the public exchequer in line with his ability-to-pay.

3. Inclusive growth may be defined as growth that promotes equal opportunities and increases access to these opportunities, i.e. growth that allows all members of society to participate in and contribute equally to development efforts, regardless of individual circumstances. This concept appears in Asian Development Bank's (ADB) Strategy 2020 that examines the extent of inequality of opportunities and to what extent it can be overcome by different types of growth process. The main idea in the ADB's approach is to focus on productive employment as an important element of inclusive growth. Inclusive growth, defined in a broader sense has three dimensions: (1) Equity among all sections of the society. (2) Equity among all sectors of the economy. (3) Equity among all regions in the country. Thus, inclusive growth means intergroup, inter-sector as well as inter-regional equity. Growth is inclusive when it creates economic opportunities along with ensuring equal access to them.

4. Agricultural income is exempt from tax under section 10 (1) of the Income Tax Act, 1961.

5. Derivative in mathematics means a variable derived from another variable. The term derivative indicates that it has no independent value, i.e. its value is entirely derived from the value of the underlying asset. The underlying asset can be security, commodity, bullion, currency, live stock or anything else. In other words, derivative means a forward, future, option or any other hybrid contract of pre-determined fixed duration, linked for the purpose of contract fulfilment to the value of a specified real or financial asset of an index of securities. Similarly, in the financial sense, a derivative is a financial product, which has been derived from a market for another product. Without the underlying product, derivatives do 
not have any independent existence in the market.

Derivative instruments are defined by the Indian Securities Contracts (Regulation) Act, 1956 to include (1) a security derived from a debt instrument, share, secured/unsecured loan, risk instrument or contract for differences, or any other form of security and (2) a contract that derives its value from the prices/index of prices of underlying securities. In other words, derivatives are financial instruments/contracts whose value depends upon the value of an underlying. Since their value is essentially derived out of an underlying, they are financial abstractions whose value is derived mathematically from the changes in the value of the underlying.

The International Monetary Fund (IMF) defines derivatives as "financial instruments that are linked to a specific financial instrument or indicator or commodity and through which specific financial risks can be traded in financial markets in their own right. The value of a financial derivative derives from the price of an underlying item, such as an asset or index. Unlike debt securities, no principal is advanced to be repaid and no investment income accrues".

6. TDS is a system of collecting income tax whereby money is periodically deducted by the employers, financial institutions, and others from wages of employees, returns on securities, and other payments. Thus, intermediaries (or third parties) do the job on behalf of the government as regards assessment of the taxable base and the collection of tax thereon. Generally, a fixed percentage is withheld from the payment made and the same is deposited in government's account. At the time of filing the return of income, the taxpayer encloses withholding tax receipts and in case of overpayment he can claim refund of tax. Tax withholding system (also called tax deduction at source or Pay-As-You-Earn) satisfies the canon of convenience both for the fiscal authorities and the taxpayers. It is beneficial for the government because it reduces the possibility of tax evasion, ensures prompt tax payment, and simplifies tax collection. It does not allow any lag between the time of receiving income and the time of tax payment. For the taxpayer, it is an instalment plan of taxation and hence convenient. However, tax withholding involves additional paper work on the part of tax deductors. It also adds to the burden of taxpayers who have to obtain tax deduction certificates from deductors, fill additional tax forms, and wait for refunds.

7. Presumptive Tax: In every country, there are some soft-to-tax and hard-to-tax sources of income. Wages and salaries are properly recorded and therefore it is easy to assess and collect taxes on them through the Pay-As-You-Earn (PAYE) system. Similarly, income from securities paid through banks can easily be subjected to deduction at source. Contrarily, the three hard-to-tax classes of the non-corporate sector are: (a) unincorporated commercial and industrial units, (b) self-employed professionals, and (c) rich peasantry. The problem of taxing the first two categories relates to accounting difficulties while in the case of third category, it is essentially the lack of political will. Non-reporting and under-reporting of income is quite sizeable in these sectors. The growing small business sector is a tax haven. It is very difficult to enforce a reliable system of book-keeping to assess earnings of this sector. 
Pragmatically, a system of lump sum taxation may be tried in place of taxation of profits.

Presumptive tax relates to the use of appropriate indicators of income, wealth etc. instead of the actual records of these tax bases. In the case of income tax, a presumptive tax is imposed on the basis of an estimated taxable income. Presumptive income is exogenously determined. The base for the presumptive income tax is fixed and does not depend on the behaviour of individual entrepreneurs. In essence, a presumptive income tax works like a lump sum tax and therefore does not impose marginal tax burden on actual income. Varying methods of presumptive taxation are in operation in Israel, Argentina, Chile, and Columbia. The French forfait system is a typical example of presumptive taxation. The chief advantage of presumptive taxation is its simplicity, both for the tax collectors and the taxpayers. It is, therefore, cost-effective for the administration. The simplicity attribute may also encourage tax compliance. Presumptive taxation particularly suits the developing countries with a large unorganised business sector consisting of small retail establishments, and self-employed professionals. It is easy to administer this tax which can become an effective source of revenue. It also promotes horizontal equity.

The French forfait system has several features. Firstly, the taxable profit of a given business unit is agreed upon mutually between the tax authorities and the assessee. Secondly, the assessment remains valid for a limited number of years. Finally, the taxpayer is required to submit a set of simple facts to the authorities, namely the amount of his purchases and sales, the wage bill, the value of his inventory, and the number of employees. Alternatively, small businesses may be subject to a system of licence fee charged in accordance with some welldefined criteria such as the location of business and its size.

\section{References}

Government of India (1953-54), Ministry of Finance, Report of the Taxation Enquiry Commission (Chairman, John Matthai), Volume II.

Government of India, Ministry of Finance, Report of the Direct Taxes Administration Enquiry Committee (Chairman: Mahavir Tyagi), 1958-59.

Government of India (1971), Ministry of Finance, Final Report of Direct Taxes Enquiry Committee (Chairman, Justice K.N. Wanchoo), December.

Government of India (1973). Ministry of Finance, Report of the Central Excise (SelfRemoval Procedure) Review Committee (Chairman: B. Venkatappiah), 1973. 
34 |VISION: Journal of Indian Taxation, Volume 2, Issue 1

Government of India (1991). Ministry of Finance, Interim Report of the Tax Reforms Committee (Chairman: Raja Chelliah), December.

Government of India. Planning Commission, Seventh Five Year Plan (1985-90), Vol I.

Government of India. Planning Commission, Ninth Five Year Plan (1997-2002), Vol I.

Government of India, Ministry of Finance, Budget 1997-98, Speech of the Finance Minister, Part B.

Kaldor, Nicholas (1956) Indian Tax Reform: Report of a Survey (Government of India, Ministry of Finance). 